\title{
ENVIRONMENTAL EFFECTS ON THE DISTRIBUTION OF CHIASMATA AMONG NUCLEI AND BIVALENTS AND CORRELATION BETWEEN BIVALENTS
}

\author{
CHARLES G. ELLIOTT \\ Department of Genetics, University of Glasgow
}

1. INTRODUCTION

Received 3.i. 58

IT is known from cytological evidence in a number of plants and animals that chiasma formation is not always independent in different bivalents, but may be correlated. Genetical evidence in Drosophila also indicates that crossing-over in different bivalents is correlated when inversions are present in heterozygous condition. A positive correlation between the chiasma frequencies of two bivalents means that when the number of chiasmata in one is low, it tends to be low in the other in the same nucleus; high chiasma frequencies in one will be associated with high chiasma frequencies in the other. In the case of a negative correlation, a high number of chiasmata in one bivalent is associated with a low number in the other in the same nucleus.

When genetical mapping is done by selection of recombinants as in micro-organisms, correlations in crossing-over may have important effects on the observed frequencies of recombination. In a genetical study of such correlations, it is difficult to follow crossing-over in more than two bivalents simultaneously, owing to the limited number of marker genes which can be handled in a single experiment. Cytological studies of chiasma frequency possess the advantage that we can readily follow all bivalents.

In a sample of $n$ nuclei, each with $k$ bivalents (all of which are individually distinguishable), the variation in chiasma frequency over all bivalents can be partitioned as follows (Mather, 1936) :-

\begin{tabular}{|c|c|}
\hline Component of variation & Degrees of freedom \\
\hline Between nucl & $n-1$ \\
\hline Between means for bivalents (interbivalent) & $k-\mathbf{I}$ \\
\hline Inherent . & $(k-I)(n-I)$ \\
\hline
\end{tabular}

If the internuclear variance is equal to the inherent variance, there is no correlation between bivalents. If the internuclear variance is greater than the inherent variance, there is a positive correlation. If the internuclear variance is less than the inherent variance, there is a negative correlation (Mather, I936). The internuclear variance measures the variation in the total numbers of chiasmata per nucleus in the sample, while the inherent variance measures the variation in the distribution of chiasmata among the bivalents of the individual nuclei. 
This paper describes the effect of temperature on these variances and on the correlation between bivalents in two liliaceous plants, the bluebell, Endymion non-scriptus, and a diploid variety of hyacinth (Yellow Hammer).

\section{MATERIAL}

All the plants of Endymion non-scriptus used in this investigation came from Madingley Wood, near Cambridge. Group I bulbs were undergoing meiosis when collected on 2 ist December 1952. Group II bulbs were collected on 18th October 1952 and placed in pots of soil in controlled temperature chambers (see Elliott, 1955).

The hyacinth material and the temperature treatments given have been described previously (Elliott, 1955).

Chiasma frequencies were scored at first metaphase in temporary acetocarmine squashes of anthers.

\section{METHOD OF ANALYSIS}

In Endymion non-scriptus, the eight chromosomes of the haploid set are designated $A$ to $\mathrm{H}$ in decreasing order of length (Darlington, 1926). At $\mathrm{M}-\mathrm{I}$ of meiosis, all the bivalents except B, C and D can be recognised individually (plate). B, C and $\mathrm{D}$ are treated as a single group. In the analysis of variance ( $c f$. table, p. 429 ), the interbivalent variance therefore has only $k-3=5$ degrees of freedom. The internuclear variance still has $n-I$ degrees of freedom. If all remaining degrees of freedom contributed to the inherent variance, this would include an item with 2 degrees of freedom (out of the original $k-1$ of the interbivalent variance) for variation between the means of the three bivalents grouped together. However, we can separate an item with $2 n$ degrees of freedom for all variation within nuclei between B, C and D. We thus replace the observed chiasma frequencies of B, $\mathrm{C}$ and $\mathrm{D}$ by three equal values in each nucleus. This leaves $5(n-1)$ degrees of freedom for the inherent variance, which measures the departures from the expected values of the observed values of the chiasma frequencies for $A, E, F, G$ and $H$ and the values, as obtained above, for B, C and D.*

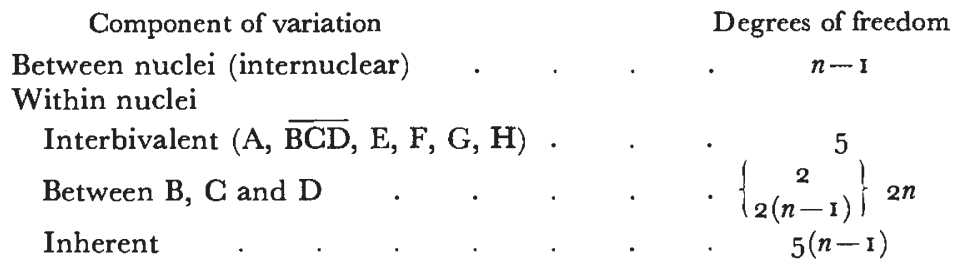

At $\mathrm{M}-\mathrm{I}$ in diploid hyacinths, $4 \mathrm{~L}, 2 \mathrm{M}$ and $2 \mathrm{~S}$ bivalents can be recognised, but the members of each group cannot be distinguished. For the analysis of whole nuclei, the variation within nuclei between the bivalents grouped together is again removed before finding the inherent variance, as follows :-

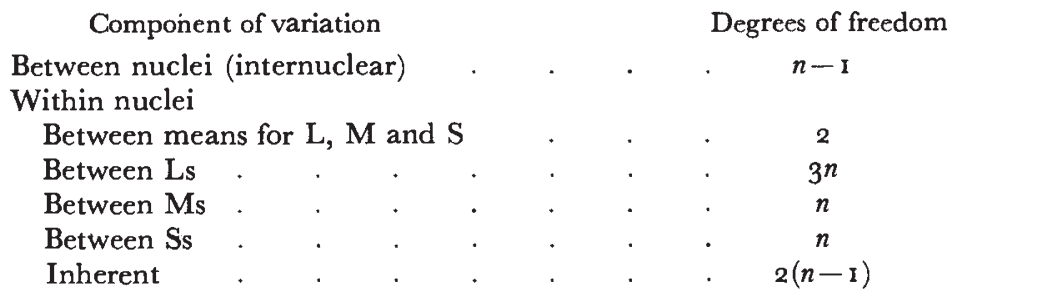

* I am indebted to Dr B. I. Hayman for this method of analysis. 


\section{RESULTS WITH ENDYMION NON-SCRIPTUS}

Table I gives the mean chiasma frequency per nucleus and the internuclear and inherent variances for each plant, and table 2 tests of heterogeneity of the variances.

TABLE I

Analysis of variance of chiasma frequency and correlation between bivalents in Endymion non-scriptus

\begin{tabular}{|c|c|c|c|c|c|}
\hline Plant no. & $\begin{array}{l}\text { No. of } \\
\text { cells } \\
(n)\end{array}$ & $\begin{array}{l}\text { Mean Xta } \\
\text { per nucleus }\end{array}$ & $\begin{array}{l}\text { Internuclear } \\
\text { variance } \\
(n-\mathrm{I}) \text { d.f. }\end{array}$ & $\begin{array}{l}\text { Inherent } \\
\text { variance } \\
5(n-1) \text { d.f. }\end{array}$ & $\begin{array}{l}\text { Correla- } \\
\text { tion * }\end{array}$ \\
\hline \multicolumn{6}{|c|}{ Group I : Meiosis under natural conditions } \\
\hline $\begin{array}{lr}\text { MW } & \text { 10 } \\
\text { MW } & 6 \\
\text { MW } & 1 \text { I } \\
\text { MW } & 8 \\
\text { MW } & \text { I }\end{array}$ & $\begin{array}{l}40 \\
40 \\
40 \\
40 \\
4^{\circ}\end{array}$ & $\begin{array}{l}16 \cdot 50 \\
18 \cdot 40 \\
19 \cdot 33 \\
21 \cdot 30 \\
23 \cdot 30\end{array}$ & $\begin{array}{l}0.3397 \\
0.253^{2} \\
0.4513 \\
0.3667 \\
0.2770\end{array}$ & $\begin{array}{l}0.3412 \\
0.3240 \\
0.33^{2} \text { I } \\
0 \cdot 23^{82} \\
0 \cdot 3^{8} 7^{6}\end{array}$ & $\begin{array}{l}0 \\
0 \\
0 \\
+ \\
0\end{array}$ \\
\hline \multicolumn{6}{|c|}{ Group II : Meiosis at controlled temperatures } \\
\hline $\begin{array}{r}I^{\circ} 5^{2 / 1 / 2} \\
5^{2 / 1} / 1 \\
5^{2 / 1} / 3\end{array}$ & $\begin{array}{l}40 \\
40 \\
20\end{array}$ & $\begin{array}{l}\text { I } 7 \cdot 68 \\
\text { I } 8 \cdot 48 \\
\text { I } 8 \cdot 55\end{array}$ & $\begin{array}{l}0.5083 \\
0.2756 \\
0.7299\end{array}$ & $\begin{array}{l}0.3901 \\
0.3 \text { I } 08 \\
0.2987\end{array}$ & $\begin{array}{l}0 \\
0 \\
+\end{array}$ \\
\hline $\begin{array}{r}5^{\circ} 5^{2 / 5 / 2} \\
5^{2} / 5 / 3 \\
5^{2} / 5 / 1\end{array}$ & $\begin{array}{l}4^{\circ} \\
4^{\circ} \\
40\end{array}$ & $\begin{array}{l}16 \cdot 3^{8} \\
16 \cdot 93 \\
17 \cdot 50\end{array}$ & $\begin{array}{l}0.3570 \\
0.3999 \\
0.6090\end{array}$ & $\begin{array}{l}0.3298 \\
0 \cdot 2753 \\
0.3393\end{array}$ & $\begin{array}{l}0 \\
0 \\
+\end{array}$ \\
\hline $\begin{array}{l}\text { I } 5^{\circ} 5^{2 / 15 / 6} \\
5^{2 / 1} 5 / 5 \\
5^{2 / 15 / 1} \\
5^{2 / 15 / 4} \\
5^{2 / 15 / 7} \\
5^{2 / 15 / 3}\end{array}$ & $\begin{array}{l}40 \\
40 \\
40 \\
40 \\
40 \\
20\end{array}$ & $\begin{array}{l}\text { I } 6 \cdot 30 \\
17 \cdot 30 \\
17 \cdot 65 \\
18 \cdot 18 \\
19 \cdot 30 \\
19 \cdot 50\end{array}$ & $\begin{array}{l}0.23^{85} \\
0.6615 \\
0.703^{8} \\
0.5634 \\
0.4372 \\
0.3^{6} 18\end{array}$ & $\begin{array}{l}0.4400 \\
0.3^{803} \\
0.3^{8} 33 \\
0.3^{822} \\
0.4^{867} \\
0.3^{6} 73\end{array}$ & $\begin{array}{l}\bar{t} \\
+ \\
0 \\
0 \\
0\end{array}$ \\
\hline $\begin{array}{r}51 / 10 / 5 \\
\text { Anther I } \\
2 \\
3\end{array}$ & $\begin{array}{l}20 \\
26 \\
14\end{array}$ & $\begin{array}{l}16 \cdot 90 \\
16 \cdot 62 \\
16 \cdot 29\end{array}$ & $\begin{array}{l}0.3^{80} 3 \\
0.1408 \\
0.5^{275}\end{array}$ & $\begin{array}{l}0.2404 \\
0.2968 \\
0 \cdot 1795\end{array}$ & $\frac{0}{+}$ \\
\hline
\end{tabular}

* + and - : correlations, positive or negative, significant at the 5 per cent. level. 0 : no correlation between bivalents.

In four of the five plants which were undergoing meiosis under natural conditions (Group I), there is no correlation between the chiasma frequencies of the bivalents. In one plant there is a positive correlation (table I). Both the internuclear and inherent variances for all five plants are homogeneous (table 2). As the ratio of the pooled variances indicates no correlation between bivalents, the plant with a positive correlation does not constitute a significant deviation from the population as a whole.

The experimental plants of Group II present a different picture. 
Here a number of plants show a positive correlation between bivalents and others absence of correlation, and one plant shows a negative correlation between bivalents (table $\mathrm{I}$ ). Inspection of table $\mathrm{I}$ indicates that there is no relation between the type of correlation observed and the mean chiasma frequency of the plant.

The data for $5 \mathrm{I} / \mathrm{IO} / 5$, a plant used in a temperature experiment in I95 I, comprise scores for three separate anthers. Anthers 2 and 3 came from the same flower, anther I from a different flower on the same inflorescence. Anther I shows no correlation between bivalents; in anther 2 there is a negative correlation, and in anther 3 a positive correlation (table I). The three anthers do not differ significantly in mean chiasma frequency.

TABLE 2

Tests of heterogeneity of the variances in table I

\begin{tabular}{|c|c|c|c|c|c|c|}
\hline & \multicolumn{3}{|c|}{ Internuclear variances } & \multicolumn{3}{|c|}{ Inherent variances } \\
\hline & $\chi^{2}$ & D.f. & $P$ & $\chi^{2}$ & D.f. & $\mathrm{P}$ \\
\hline $\begin{array}{l}\text { Group I } \\
\text { Group II }\end{array}$ & 4.09 & 4 & $0.5-0.3$ & $8 \cdot 94$ & 4 & $0.1-0.05$ \\
\hline $\begin{array}{l}\text { Within temperatures } \\
\text { Between temperatures } \\
\text { Anthers of plant } 5^{1 / 10 / 5}\end{array}$ & $\begin{array}{r}24 \cdot 35 \\
0 \cdot 60 \\
8 \cdot 71\end{array}$ & $\begin{array}{l}9 \\
2 \\
2\end{array}$ & $\begin{array}{l}0.01-0.001 \\
0.8-0.7 \\
0.001\end{array}$ & $\begin{array}{r}12 \cdot 09 \\
13.90 \\
5 \cdot 00\end{array}$ & $\begin{array}{l}9 \\
2 \\
2\end{array}$ & $\begin{array}{l}0.3-0.2 \\
0.01-0.001 \\
0.1-0.05\end{array}$ \\
\hline
\end{tabular}

The inherent variances are homogeneous for the plants within each temperature treatment in Group II and for the anthers of plant $5 \mathrm{I} / \mathrm{Io} / 5$ (table 2), and are therefore not associated with the different types of correlation observed. The corresponding internuclear variances are, however, heterogeneous, and we observe that positive correlations are associated with large internuclear variances, and negative correlations with small internuclear variances. The striking feature of these results is that different types of correlation are associated with differences in internuclear variance without any change in inherent variance.

Two different effects of environment on the internuclear and inherent variances are evident in these results :

\section{(i) An effect of temperature on the inherent variance}

The inherent variance measures the variation from cell to cell in the distribution of chiasmata among the bivalents of the nuclei. The variances for the plants at each temperature do not differ significantly, but there are differences between temperatures (table 2).

$\begin{array}{cc}\text { Temperature } & \text { Mean inherent variance } \\ 1^{\circ} & 0.3332 \\ 5^{\circ} & 0.3148 \\ 15 & 0.4066\end{array}$


There is an effect of temperature on the inherent variance, which is minimal at $5^{\circ}$, although the difference between the mean variances at $1^{\circ}$ and $5^{\circ}$ is not significant; the difference between them at $5^{\circ}$ and $15^{\circ}$ is significant.

The relation between the inherent variation and the variation of the individual bivalents in chiasma frequency is given by

Inherent sum of squares $=\Sigma(a-\bar{a})^{2}+\frac{1}{3} \Sigma[(b+c+d)-(\bar{b}+\bar{c}+\bar{d})]^{2}$ $+\Sigma(e-\bar{e})^{2}+\ldots \ldots+\Sigma(h-h)^{2}$-Internuclear sum of squares

where $a, b, \ldots$ are the chiasma frequencies of the individual $\mathrm{A}, \mathrm{B}, \ldots$ bivalents, and $\bar{a}, \bar{b}, \ldots$ their means. We see from this equation that for a given amount of internuclear variation, an increase in the inherent variation is associated with increased variation in the chiasma frequencies of the individual bivalents. It may be that the observed effect of temperature on the inherent variance arises from an effect on the variability of the extent of chromosome pairing during meiotic prophase. At $15^{\circ}$ pairing is less regular than at the lower temperatures; hence variation in the chiasma frequency of the individual bivalents is greater, and there is a corresponding increase in inherent variance.

\section{(ii) An effect of some unknown factor on the internuclear variance}

The internuclear variance measures the range in numbers of chiasmata per nucleus of the pollen mother cells. The variances are heterogeneous between plants in each temperature treatment, but not between temperatures (table 2). The heterogeneity of the internuclear variances for the three anthers of plant $5 \mathrm{I} / \mathrm{IO} / 5$ clearly cannot be due to genetical causes, and it may well be that the heterogeneity between plants at each temperature in Group II is likewise not due to genotypic differences, since the variances are homogeneous in Group I. Something has happened to the experimental plants which has upset the normal control of the amount of variation between nuclei in many of them, irrespective of the temperature at which they were placed. Different parts of one plant may even be differently affected. We postulate that these changes in the internuclear variance are the result of environmental effects on an extranuclear factor acting on the nuclei of the pollen mother cells and determining the distribution of chiasmata among them.

\section{RESULTS WITH HYACINTHUS}

(i) Analysis of whole nuclei

Table 3 gives the numbers of bulbs, flowers and nuclei scored at each of the temperatures used. The analysis of variance was carried out separately for each flower, and table 3 gives the mean internuclear and inherent variances (weighted according to the numbers of degrees of freedom for each sample). Table 4 gives tests of heterogeneity of the variances for the flowers at each temperature and between temperatures. 
The main interest of the results with hyacinths is in the pooled results for the different temperatures. The internuclear variances do not differ significantly between the three temperatures $20^{\circ}, 15^{\circ}$ and

TABLE 3

Summary of analysis of variance of chiasma frequency and correlation between bivalents in Hyacinthus

\begin{tabular}{|c|c|c|c|c|c|c|}
\hline \multirow{2}{*}{$\begin{array}{l}\text { Temper- } \\
\text { ature }\end{array}$} & \multicolumn{3}{|c|}{ Numbers of } & \multirow{2}{*}{$\begin{array}{l}\text { Internuclear } \\
\text { variance }\end{array}$} & \multirow{2}{*}{$\begin{array}{l}\text { Inherent } \\
\text { variance }\end{array}$} & \multirow{2}{*}{$\begin{array}{c}\text { Correla } \\
\text { tion }\end{array}$} \\
\hline & Bulbs & Flowers & Nuclei & & & \\
\hline $\begin{array}{r}20^{\circ} \\
15^{\circ} \\
10^{\circ} \\
5^{\circ}\end{array}$ & $\begin{array}{l}4 \\
4 \\
4 \\
6\end{array}$ & $\begin{array}{r}8 \\
8 \\
8 \\
15\end{array}$ & $\begin{array}{l}375 \\
400 \\
371 \\
600\end{array}$ & $\begin{array}{l}0.4068 \\
0.4720 \\
0.4627 \\
1.9642\end{array}$ & $\begin{array}{l}0.3600 \\
0.3227 \\
0.4339 \\
0.5133\end{array}$ & $\begin{array}{l}0^{a} \\
+^{b} \\
o^{c} \\
+\end{array}$ \\
\hline
\end{tabular}

a Positive correlation in one flower, and negative correlation in one.

$\checkmark$ Positive correlations in four flowers.

- Negative correlation in one flower.

$10^{\circ}$; at $5^{\circ}$ the variance is much greater. The inherent variances for the four temperatures are, however, heterogeneous. As in the bluebell, there is an effect of temperature on the inherent variance, which is here minimal at $15^{\circ}$. The differences between the mean

TABLE 4

Tests of heterogeneity of the variances in flowers of Hyacinthus

\begin{tabular}{|c|c|c|c|c|c|c|}
\hline & \multicolumn{3}{|c|}{ Internuclear variances } & \multicolumn{3}{|c|}{ Inherent variances } \\
\hline & $x^{2}$ & D.f. & $\mathbf{P}$ & $\chi^{2}$ & D.f. & $\mathbf{P}$ \\
\hline $\begin{array}{l}\text { Between temperatures } \\
20^{\circ}, 15^{\circ}, 10^{\circ}, 5^{\circ} \\
20^{\circ}, 15^{\circ}, 10^{\circ} .\end{array}$ & $\begin{array}{l}45^{2} \\
2 \cdot 43\end{array}$ & $\begin{array}{l}3 \\
2\end{array}$ & $\begin{array}{c}<0.001 \\
0.3-0.2\end{array}$ & $70 \cdot 14$ & 3 & $<0.001$ \\
\hline 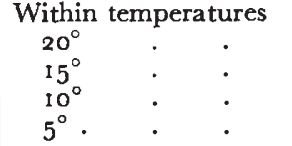 & $\begin{array}{r}18 \cdot 65 \\
5 \cdot 52 \\
12 \cdot 14 \\
36 \cdot 97\end{array}$ & $\begin{array}{r}7 \\
7 \\
7 \\
14\end{array}$ & $\begin{array}{l}0.01-0.001 \\
0.7-0.5 \\
0.1-0.05 \\
<0.001\end{array}$ & $\begin{array}{r}7 \cdot 10 \\
7 \cdot 09 \\
16 \cdot 31 \\
19 \cdot 19\end{array}$ & $\begin{array}{r}7 \\
7 \\
7 \\
14\end{array}$ & $\begin{array}{l}0.5-0.3 \\
0.5-0.3 \\
0.05-0.02 \\
0.2-0.1\end{array}$ \\
\hline
\end{tabular}

variances at $5^{\circ}$ and $10^{\circ}$ and at $10^{\circ}$ and $15^{\circ}$ are significant, but that between them at $15^{\circ}$ and $20^{\circ}$ is not significant.

At each of the temperatures $20^{\circ}$ and $10^{\circ}$ the mean internuclear and inherent variances do not differ significantly, so there is no correlation between bivalents for these temperatures as a whole. At $15^{\circ}$ the internuclear and inherent variances differ, indicating a positive correlation (table 3 ). It is to be noted that while the internuclear variances are the same for the three higher temperatures, the inherent variance is lower at $15^{\circ}$ than at $20^{\circ}$ and $10^{\circ}$. We may therefore 
associate the positive correlation at $15^{\circ}$ with a change in the inherent variance, in contrast to the results at one given temperature in bluebells.

At $5^{\circ}$, the analysis of variance indicates a positive correlation between the chiasma frequencies of the bivalents, and this bears out the observation of a positive correlation in their pairing behaviour. For each of the chromosome types, L, M and S, more nuclei have all univalents or all bivalents than is expected by chance (Elliott, I955).

Within temperatures, the inherent variances are homogeneous, as in bluebells, although they are heterogeneous at $10^{\circ}$.

Again within temperatures, the internuclear variances are heterogeneous at $20^{\circ}$ and $5^{\circ}$, and homogeneous at $15^{\circ}$ and $10^{\circ}$. That is to say, at $20^{\circ}$ and $5^{\circ}$ there is more variation in chiasma frequency between the nuclei in some samples of pollen mother cells than in others, while at $15^{\circ}$ and $10^{\circ}$ the variation between the nuclei of the p.m.c. does not differ significantly between samples. Thus while temperature does not affect the mean variance of the distribution of chiasmata between nuclei, except at $5^{\circ}$, we may say that it strongly affects the "stability" of this distribution.

At $20^{\circ}$ the negative correlation observed in one flower is associated with a low internuclear variance, and the positive correlation in another with a high internuclear variance. The negative correlation in one flower at $10^{\circ}$ is also associated with a low internuclear variance. Thus within temperatures the relation between different types of correlation is the same as that observed in the bluebells.

\section{(ii) Interrelationships of the grouped bivalents}

The inherent variance as calculated above measures the variation from cell to cell between the three classes of bivalents, L, M and S. We now consider the relationships between the bivalents in each of the three groups. The variation between and within nuclei for each group has been calculated in the usual way for four of the flowers at each temperature, and table 5 gives the pooled variances, and the type of correlation between the bivalents of each group for the temperature as a whole.

The variation between bivalents within nuclei differs significantly between temperatures (table 5), but unlike the inherent variance discussed above, it is less at $20^{\circ}$ than at $15^{\circ}$ for each class of bivalent, significantly so for the $\mathrm{L}$ and $\mathrm{M}$ chromosomes. It cannot be said whether this represents a real difference between the variance of the distribution of chiasmata to the three groups and that to the bivalents of the groups. Clearly, however, the variation between bivalents is affected by temperature.

The variation between nuclei for the $L$ and $M$ bivalents does not differ significantly between the three higher temperatures (table 5), as is the case also for the whole nuclei, but for the $\mathrm{S}$ bivalents there is more variation between nuclei at $10^{\circ}$ than at $15^{\circ}$ and $20^{\circ}$. This may be explained by the frequent failure of the $\mathbf{S}$ chromosomes to form 
bivalents at low temperature, which is experienced by the $\mathrm{L}$ and $\mathbf{M}$ chromosomes only at $5^{\circ}$.

\section{THE ROLE OF DIFFERENT BIVALENTS IN CORRELATED SYSTEMS IN ENDYMION NON-SCRIPTUS}

From a genetical standpoint, the correlations between the bivalents of the nucleus as a whole are of less interest than correlations between the chiasma frequencies of one particular bivalent and another or

TABLE 5

Summary of analysis of variance of chiasma frequency of and correlation between the $L, M$ and $S$ bivalents of Hyacinthus

\begin{tabular}{|c|c|c|c|c|c|c|c|c|c|}
\hline \multirow{2}{*}{$\begin{array}{l}\text { Temper- } \\
\text { ature }\end{array}$} & \multicolumn{3}{|c|}{$\mathrm{L}$} & \multicolumn{3}{|c|}{ M } & \multicolumn{3}{|c|}{$\mathbf{S}$} \\
\hline & $\begin{array}{l}\text { Between } \\
\text { nuclei }\end{array}$ & $\begin{array}{l}\text { Within } \\
\text { nuclei }\end{array}$ & $\begin{array}{c}\text { Cor- } \\
\text { relation * }\end{array}$ & $\begin{array}{c}\text { Between } \\
\text { nuclei }\end{array}$ & $\begin{array}{l}\text { Within } \\
\text { nuclei }\end{array}$ & $\begin{array}{c}\text { Cor- } \\
\text { relation * }\end{array}$ & $\begin{array}{c}\text { Between } \\
\text { nuclei }\end{array}$ & $\begin{array}{l}\text { Within } \\
\text { nuclei }\end{array}$ & $\begin{array}{c}\text { Cor- } \\
\text { relation * }\end{array}$ \\
\hline $\begin{array}{l}20^{\circ} \\
15^{\circ} \\
10^{\circ} \\
5^{\circ}\end{array}$ & $\begin{array}{l}0.5889 \\
0.64 \text { I } 7 \\
0.7445 \\
2.0703\end{array}$ & $\begin{array}{l}0.5016 \\
0.6217 \\
0.8954 \\
0.7625\end{array}$ & $\begin{array}{l}0 \\
0 \\
\frac{1}{1}\end{array}$ & $\begin{array}{l}0.3603 \\
0.35^{81} \\
0.3740 \\
0.7505\end{array}$ & $\begin{array}{l}0.2450 \\
0.3625 \\
0.4100 \\
0.4025\end{array}$ & $\begin{array}{l}+^{a} \\
0 \\
0 \\
+\end{array}$ & $\begin{array}{l}0.1074 \\
0.1328 \\
0.2544 \\
0.6351\end{array}$ & $\begin{array}{l}0.1375 \\
0.1500 \\
0.2800 \\
0.2900\end{array}$ & $\begin{array}{l}- \\
0 \\
0^{b} \\
+\end{array}$ \\
\hline \multicolumn{10}{|c|}{ Heterogeneity between temperatures } \\
\hline $\begin{array}{c}20^{\circ}, 15^{\circ} \\
10^{\circ}, 5^{\circ} \\
\chi^{2}[3] \\
20^{\circ}, 15^{\circ} \\
10^{\circ} \\
\chi^{2}[2]\end{array}$ & $\begin{array}{c}\cdots \\
2 \cdot 78\end{array}$ & $55^{\circ} 9^{*}$ & $\cdots$ & $0 \cdot 11$ & $16 \cdot 1 *$ & $\cdots$ & $4^{I} \cdot 4^{*}$ & $45^{\circ} 8^{*}$ & $\cdots$ \\
\hline
\end{tabular}

a Significant positive correlation in two of the four flowers.

$b$ Significant negative correlation in one of the four flowers.

* Significant values at 5 per cent. level.

group of other bivalents. Endymion non-scriptus is an exceptionally favourable organism for studies of chiasma frequency as we can recognise five of the eight chromosomes at $M-I$ (plate). The following analyses have been made to determine the behaviour of the individual types of bivalents in a correlated system.

Correlation coefficients have been calculated (i) for the chiasma frequencies of the bivalents $\mathrm{A}, \mathrm{E}, \mathrm{F}, \mathrm{G}$ and $\mathrm{H}$ considered in pairs, (ii) for the numbers of chiasmata in a particular type of bivalent (including $\mathrm{B}, \mathrm{C}$ and $\mathrm{D}$ as a group) compared with the totals in the remaining bivalents (table 6 ). This has been done in plant 52/ $5 / 6$ and anther 2 of plant $5 \mathrm{I} / \mathrm{10} / 5$, in both of which the previous analysis of variance indicated a negative correlation between bivalents for the nucleus as a whole, and in $5^{2 / 15 / 5}$ and anther 3 of $5^{1 / 10 / 5}$, where there is a positive correlation. The use of correlation coefficients is open to objection, since some bivalents have only two different 
numbers of chiasmata in a sample of nuclei. In a number of cases therefore the independence of the bivalents has been examined by the exact method (Freeman and Halton, I95I). With these relatively small numbers of nuclei, few of the correlations are expected to be

TABLE 6

Correlations observed (whether positive or negative) between the chiasma frequencies of the bivalents of Endymion non-scriptus considered in pairs, and between the numbers of chiasmata in one type of bivalent and the total in the remaining bivalents. Significant correlations are indicated by an asterisk

\begin{tabular}{|c|c|c|c|c|c|c|c|c|c|c|c|c|}
\hline & \multicolumn{6}{|c|}{$52 / 15 / 6$} & \multicolumn{6}{|c|}{$52 / 15 / 5$} \\
\hline & $\mathrm{A}$ & $\mathrm{BCD}$ & $\mathrm{E}$ & $\mathrm{F}$ & $\mathrm{G}$ & $\mathrm{H}$ & A & $\mathrm{BCD}$ & $\mathrm{E}$ & $\mathrm{F}$ & G & $\mathbf{H}$ \\
\hline $\begin{array}{l}\text { A } \\
\text { E } \\
\text { F } \\
G\end{array}$ & $\begin{array}{l}\ldots \\
\cdots \\
\cdots \\
\cdots\end{array}$ & $\begin{array}{l}\ldots \\
\cdots \\
\cdots \\
\cdots\end{array}$ & $\begin{array}{c}- \\
\ldots \\
\ldots \\
\cdots\end{array}$ & $\begin{array}{c}\overline{+} \\
\cdots \\
\cdots\end{array}$ & $\begin{array}{l}\overline{-} \\
\bar{\ldots}\end{array}$ & $\begin{array}{l} \pm \\
- \\
-\end{array}$ & $\begin{array}{l}\ldots \\
\cdots \\
\cdots \\
\cdots\end{array}$ & $\begin{array}{l}\ldots \\
\cdots \\
\cdots \\
\cdots\end{array}$ & $\begin{array}{c}- \\
\cdots \\
\cdots \\
\cdots\end{array}$ & $\begin{array}{l}+ \\
+ \\
\cdots \\
\cdots\end{array}$ & $\begin{array}{l}+ \\
+ \\
\ldots\end{array}$ & $\frac{+}{-}$ \\
\hline \multirow[t]{3}{*}{$\begin{array}{l}\text { Remainder } \\
\text { of nucleus }\end{array}$} & $-*$ & $-^{*}$ & - & $-^{*}$ & - & - & $t^{*}$ & + & + & + & + & - \\
\hline & \multicolumn{6}{|c|}{$5^{1 / 10 / 5}$, anther 2} & \multicolumn{6}{|c|}{$5^{1 / 10 / 5}$, anther 3} \\
\hline & A & $B C D$ & $\mathrm{E}$ & $\mathrm{F}$ & $\mathrm{G}$ & $\mathrm{H}$ & A & $\mathrm{BCD}$ & $\mathrm{E}$ & $\mathrm{F}$ & $\mathrm{G}$ & $\mathrm{H}$ \\
\hline $\begin{array}{l}\mathrm{A} \\
\mathrm{E} \\
\mathrm{F} \\
\mathrm{G}\end{array}$ & $\begin{array}{l}\ldots \\
\cdots \\
\cdots \\
\cdots\end{array}$ & $\begin{array}{l}\ldots \\
\cdots \\
\cdots \\
\cdots\end{array}$ & $\begin{array}{l}+ \\
\ldots \\
\ldots \\
\ldots\end{array}$ & $\begin{array}{l}\overline{+} \\
\ldots \\
\cdots\end{array}$ & $\begin{array}{l}+ \\
+ \\
+ \\
\ldots\end{array}$ & $\begin{array}{l}\overline{-}^{*} \\
\overline{+}\end{array}$ & $\begin{array}{l}\ldots \\
\cdots \\
\cdots \\
\cdots\end{array}$ & $\begin{array}{l}\ldots \\
\cdots \\
\cdots \\
\cdots\end{array}$ & $\begin{array}{l}+ \\
\ldots \\
\ldots \\
\ldots\end{array}$ & $\begin{array}{c}+ \\
o \\
\ldots \\
\ldots\end{array}$ & $\frac{+}{+}$ & $\frac{+}{+}+$ \\
\hline $\begin{array}{l}\text { Remainder } \\
\text { of nucleus }\end{array}$ & - & $-^{*}$ & + & - & - & $-^{*}$ & + & + & + & $+^{*}$ & $+^{*}$ & - \\
\hline
\end{tabular}

significant. In table 6 , the symbols + and - indicate whether the correlation is positive or negative, and an asterisk that the value of the correlation coefficient is significant at the 5 per cent. level.

For the bivalents considered in pairs, the correlation is in the same direction as that for the nucleus as a whole in 25 cases, and of opposite sign in 14 . One of the 40 correlation coefficients is significant. For the comparison of one type of bivalent with the remaining bivalents, the correlation is in the same direction as that for the nucleus as a whole in 21 of the 26 cases, and 8 of the correlation coefficients are significant. Thus while the correlation between individual bivalents is generally not significant, the effects are predominantly in one direction and tend to become significant when more bivalents are considered together. In contrast to the above, in two samples where the analysis of variance indicated no correlation between bivalents, none of the correlations of table 6 is significant. 
Now the variances of the chiasma frequencies of the different bivalents are heterogeneous (table $7 ; \chi^{2}{ }_{[5]}=39 \cdot 73, \mathrm{P}<0 \cdot 001$ ). (No account of this has been taken in the analysis of variance of table $\mathrm{I}$.) Bivalent $\mathrm{E}$ has the lowest variance. Table 7 also gives the mean chiasma frequency and the variance of the distribution for the separate arms of the bivalents. It will be noticed in table 7 that there is a connexion between the variance of the distribution of numbers of

\section{TABLE 7}

Mean chiasma frequencies and variances of the distributions for the whole bivalents and for their separate arms in Endymion non-scriptus, plant $M W 6$, together with mitotic lengths of the chromosomes as a percentage of the length of the haploid set

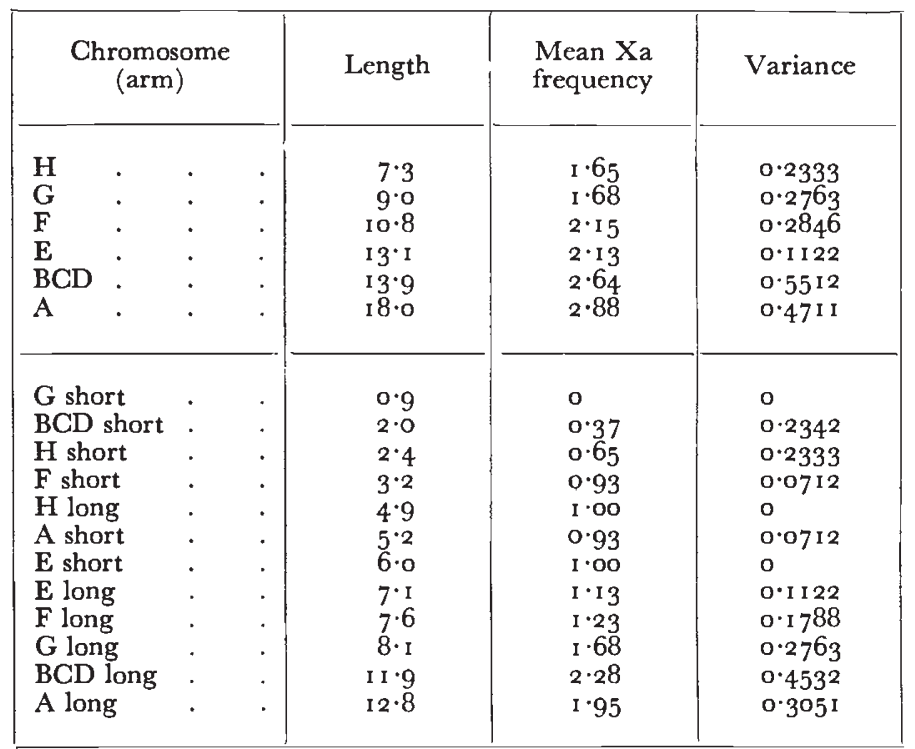

chiasmata per arm and their mean. Arms with a mean of one form one chiasma with great regularity. The variance of the whole bivalent $\mathrm{E}$ is the lowest of the six because $\mathrm{E}$ is the chromosome with most nearly equal arms and the chiasma frequency of each arm is about one. In the longer arms which may have more than one chiasma, the variance increases with the mean.

Considering the correlations between individual bivalents in table 6 , bivalent $\mathrm{A}$ showed a correlation with the other individual bivalents of the same sign as that for the nucleus as a whole in 12 out of 16 cases, $G$ and $H$ each in $I$ out of 16 cases, F in 9 out of 15 and $\mathrm{E}$ in 7 out of $\mathrm{I} 5$ cases. Thus, while none of the ratios $12: 4$ etc., deviates significantly from $\mathrm{I}: \mathrm{I}$, there is a suggestion that the occurrence of correlations between the bivalents of a nucleus is more dependent on the behaviour of the long and short chromosomes than on those of intermediate length. This is clearly related to the observation that the long arms of $A$ and $G$ and the short arm of $H$ have a greater variance of chiasma frequency than the arms of $\mathrm{E}$ and $\mathrm{F}$ (table 7 ). 


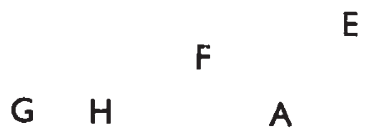

A
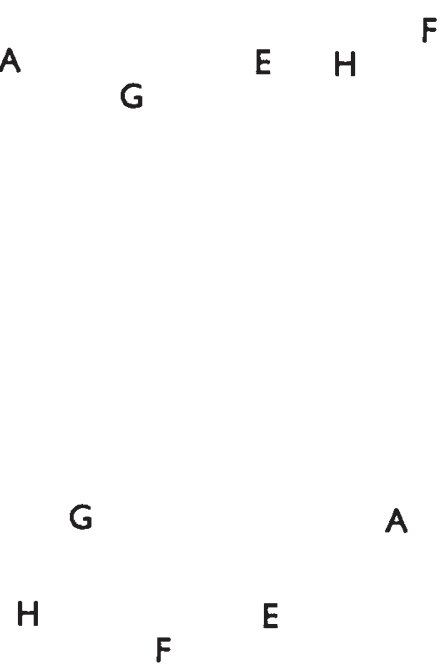

A

A

$F$

$\mathrm{H}$

Plate

First meiotic metaphase in Endymion non-scriptus.

$$
\times \text { I } 500 \text {. }
$$



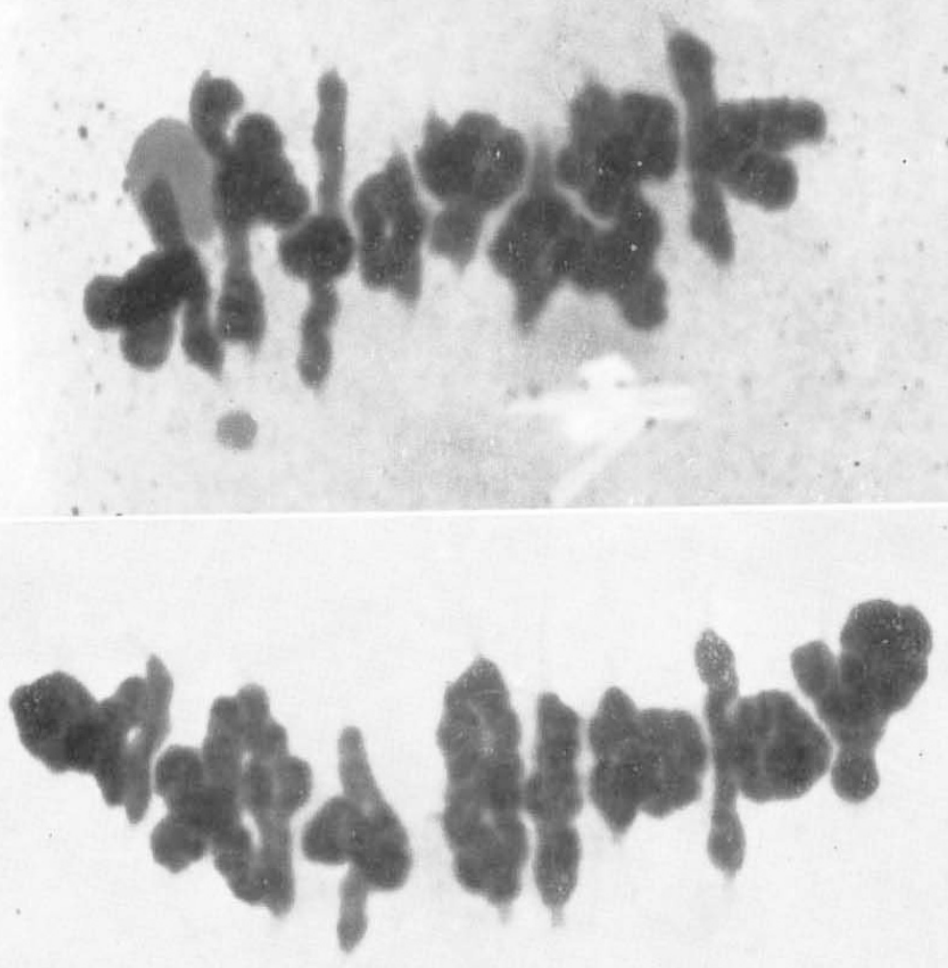

.
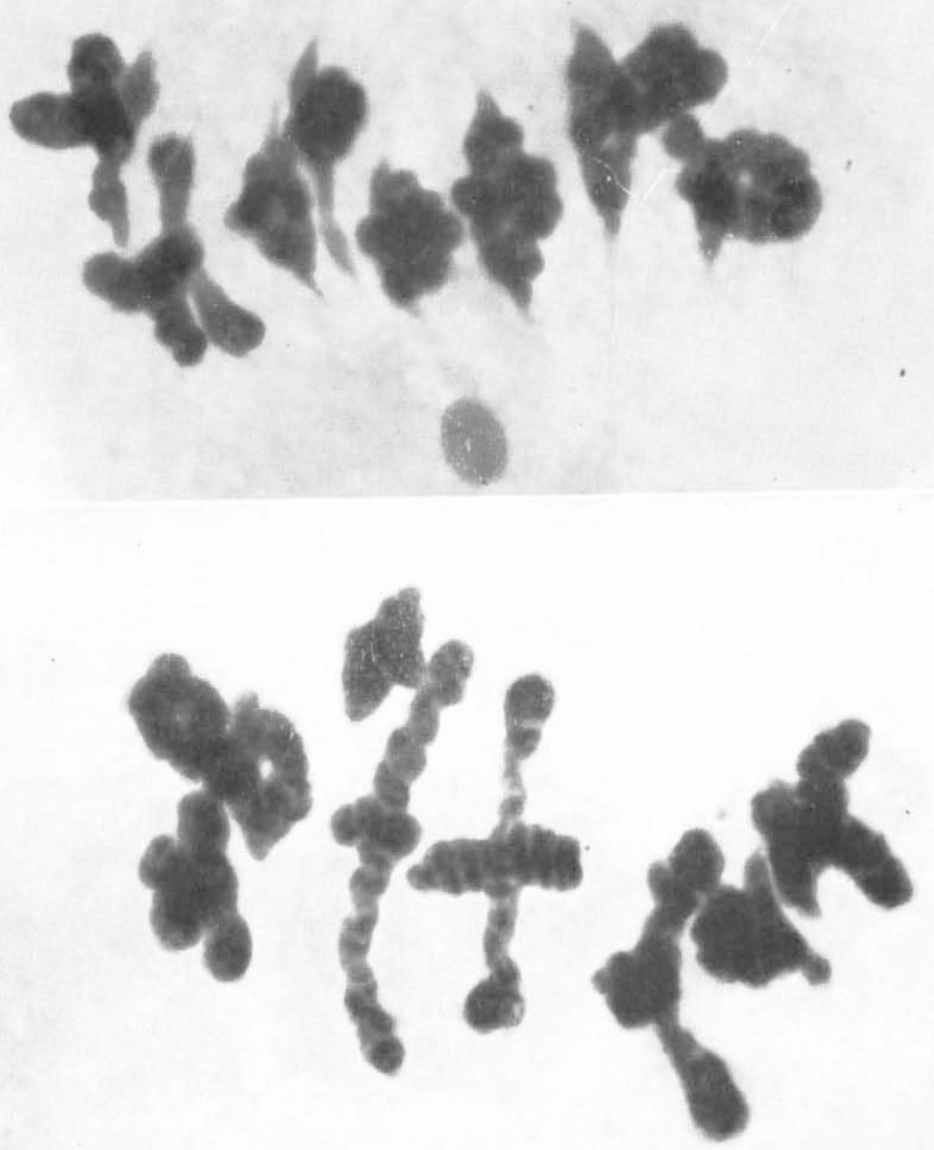


\section{SUMMARY AND CONCLUSIONS}

The variances of the distributions of chiasmata among nuclei and among the bivalents of the nuclei are differently affected by environment, suggesting they are independent and determined by different physiological processes. This is in line with the observation (Rees and Thompson, 1956) that in rye they are at least in part independently determined genetically.

Different types of correlation between the chiasma frequencies of the bivalents may be observed when one of the variances is altered without any change in the other. The results with hyacinths are especially important; here, changes with temperature in the inherent variance (between bivalents), unaccompanied by changes in the internuclear variance, were associated with different types of correlation. In Endymion non-scriptus, bulbs at the same temperature, and even different anthers in the same bulb, showed differences in internuclear variance, which, unaccompanied by changes in the inherent variance, were associated with different types of correlation.

Finally, as illustrated in Endymion, no correlation is expected between different bivalents if the variance of the chiasma frequency of one or both of them is low. If the variance for both bivalents is high, a significant correlation may occur.

\section{REFERENCES}

Darlington, C. D. 1926. Chromosome studies in the Scilleæ. 7. Genet., 16, 237-251. ELliotT, C. G. I 955. The effect of temperature on chiasma frequency. Heredity, 9, $385-398$.

FREEMAN, G. H., AND HALTON, H. J. 1951. Note on an exact treatment of contingency, goodness of fit and other problems of significance. Biometrika, $38,4^{1-1} 49$.

mather, K. I936. Competition between bivalents during chiasma formation. P.R.S., B, $120,208-227$.

REES, H., AND THOMPSON, J. B. I956. Genotypic control of chromosome behaviour in rye. III. Chiasma frequency in homozygotes and heterozygotes. Heredity, Io, $409-424$. 